Article

\title{
Development and Performance Investigation of an Inflatable Solar Drying Technology for Oyster Mushroom
}

\author{
Nguyen Van Hung ${ }^{1, *}\left(\mathbb{0}\right.$, Lei Anne Fuertes ${ }^{2}$, Carlito Balingbing ${ }^{1}$, Ampy Paulo Roxas ${ }^{1}$, \\ Marvin Tala ${ }^{2}$ and Martin Gummert ${ }^{1}$ \\ 1 International Rice Research Institute (IRRI), Los Baños 4031, Philippines; c.balingbing@irri.org (C.B.); \\ apkroxas@gmail.com (A.P.R.); m.gummert@irri.org (M.G.) \\ 2 GrainPro Philippines Inc., Zambales 2209, Philippines; leianne@grainpro.com (L.A.F.); \\ marvin@grainpro.com (M.T.) \\ * Correspondence: hung.nguyen@irri.org
}

Received: 22 June 2020; Accepted: 23 July 2020; Published: 10 August 2020

\begin{abstract}
We developed an inflatable solar dryer for mushroom drying, which was adapted from the Solar Bubble Dryer ${ }^{\mathrm{TM}}$ originally designed for paddy drying. The improved dryer with an added perforated elevated floor ensured the quality without any requirement of mixing or turning of the mushrooms during drying. Its drying performance and economic feasibility were evaluated through determination of the drying parameters including moisture content (MC) reduction, mushroom quality, energy efficiency, greenhouse gas emissions, and cost-benefits ratio. Mushroom MC was reduced from $90 \%$ down to $40-60 \%$ within $2-4 \mathrm{~h}$, corresponding to the drying rate at this stage of $10-20 \% \mathrm{~h}^{-1}$. At the next stage, it took about $4-6 \mathrm{~h}$ corresponding to a drying rate of $2-10 \% \mathrm{~h}^{-1}$ to reach the required product MC of $8-10 \%$. The color of the dried mushrooms still remained white-cream. The drying process required $4.57 \mathrm{MJ}$, emitted $0.33 \mathrm{~kg} \mathrm{CO}_{2} \mathrm{e}$, and required an input cost of $1.86 \$ \mathrm{US} \mathrm{kg}$ of dry product. For the specific case in the Philippines, this can generate a net profit of 468-1468 $\$ \mathrm{US}^{-1}$ year $^{-1}$ and the investment will break even in 1.3-4.0 years corresponding to the selling price of dry mushroom of 10-12 \$US kg-1. The study developed a solution to improve the solar bubble dryer and verified its drying process for mushroom drying at farm scale. It would add a significant value to farmers' income as well as a diversified source of nutrient-rich food.
\end{abstract}

Keywords: renewable energy; mushroom; postharvest; drying; rice straw; food

\section{Introduction}

World commercial mushroom production is about 8 million tons [1]. Out of many varieties, edible mushrooms, such as rice straw mushroom (also called "white button mushroom"), and oyster mushroom are widely cultivated in tropical countries such as China and Vietnam [2,3]. Rice straw mushroom and oyster mushroom constitute $38 \%$ and $24 \%$ of the world's mushroom production, respectively [4]. These mushrooms can be grown by using different substrates including biomass basal substrates, such as saw dust, rice straw, wheat straw, and cotton seed hull [3]. The biological efficiency (ratio between mushroom weight at harvest and dry weight of substrate used for mushroom cultivation) of rice straw mushroom is 5-10\% [2], while that of oyster mushroom is 30-130\%, depending on the substrates $[3,5,6]$. These mushrooms are not only a nutrient-rich food but also a livelihood source with healthy protein content [7-9]. These mushrooms are considered as a product of an upgraded value chain [10]. For example, Nguyen-Van-Hung et al. [11] and Le-Vinh-Thuc et al. [2] reported that rice straw mushroom production can add 50-100 \$US profit to a hectare of rice production. 
These upgraded value chains of rice and rice straw also led to a significant reduction of rice straw burning $[10,12]$. However, fresh paddy straw mushroom and oyster mushroom, which are highly perishable commodities with high moisture content (MC) ranging from $75 \%$ to $90 \%$ on a wet basis, can only be maintained for less than 2 days in ambient temperature in tropical countries without losing quality (e.g., $28-35^{\circ} \mathrm{C}$ ) [2,7]. Excess mushroom from the fresh markets are therefore processed into salted-canned and dried forms $[13,14]$. Dried mushrooms can be further processed into powder and used in food processing [15], as substitute for meat [16], and for fortification of bakery products [17]. Drying is also considered as a cost-effective method compared to the other preservation methods as it can increase the storability of mushroom up to more than a year with airtight packages [18]. Mechanical and industrial drying technologies have also been developed for mushroom drying. Convective hot-air, microwave-convective heated-air, and a combination fast heating of microwave and low-temperature convective drying technologies provide acceptable quality of dried mushroom [19]. Some more advanced technologies were also introduced and investigated, such as osmo-air drying [20,21], low temperature drying and freeze drying [22], and fluidized-bed drying [23]. On the other hand, sun drying is commonly used by small resource-poor growers as it requires zero or insignificant investment cost. However, this practice results in poor-quality products as it is strongly affected by the environment and weather [24,25]. The product is also often contaminated by dirt, insects, bacteria, etc. [26]. The constraints of sun drying can be addressed by solar drying, which does not require electric grid power and fuel, particularly for a high-MC product. Hybrid-solar drying [26,27] and solar-assisted heat pump drying [22] were introduced as advanced technologies for mushroom drying. However, these technologies usually are characterized by high investment and operating costs.

This research aimed at developing a farm-scale solar drying technology for mushrooms. We modified the Solar Bubble Dryer (SBD) originally developed for paddy drying [28-30]. An experiment was conducted using oyster mushroom to identify characteristics of the drying process based on the reduction of mushroom moisture content corresponding to the specific ambient temperature, relative humidity, and solar radiation. In addition, energy efficiency, greenhouse gas (GHG) emission, and cost-benefits were also analyzed for drying $1 \mathrm{~kg}$ of oyster mushroom. The effects of climatic factors (i.e., radiation, ambient temperature, and RH) on drying time, capacity, and cost-benefits were taken into account through a sensitivity analysis.

\section{Methodology}

\subsection{Assessment of the Solar Bubble Dryer (SBD)}

The SBD (Figure 1), developed by a consortium consisting of IRRI, University of Hohenheim, and GrainPro Inc. [28,29], was originally designed for paddy drying, but is also used for drying maize, cocoa, and coffee. The overflow drying process happens when the air streams over the spread products while flowing through the bubble drying tunnel, which is inflated by the blowers. The power for the blowers is generated by solar panels; a battery provides power during times of low radiation or at night. The solar bubble is made of plastic film with a transparent plastic cover on the top and a black reinforced polyvinyl chloride (PVC) underneath, it functions as weather protection and as a trap for solar radiation to generate heat. The drying air is heated up when flowing through this bubble tunnel and, consequently, the relative humidity (RH) is reduced to better remove moisture from the product (e.g., grains). This dryer was adapted to mushroom drying by adding an inflatable perforated elevated floor on which the mushrooms are placed. This converted the drying process from overflow drying to a hybrid of overflow drying combined with flow-through drying. The inflatable floor was developed by GrainPro as an "add on" to the SBD in order to dry some commodities more efficiently and at the same time to enable the mobility of a complete drying unit. Three parallel inflatable support beams made of reinforced polyurethane (PU) support a polyethylene (PE) mesh which is stretched over the PU beams. The beams are kept separated at the bottom by aluminum strips. 


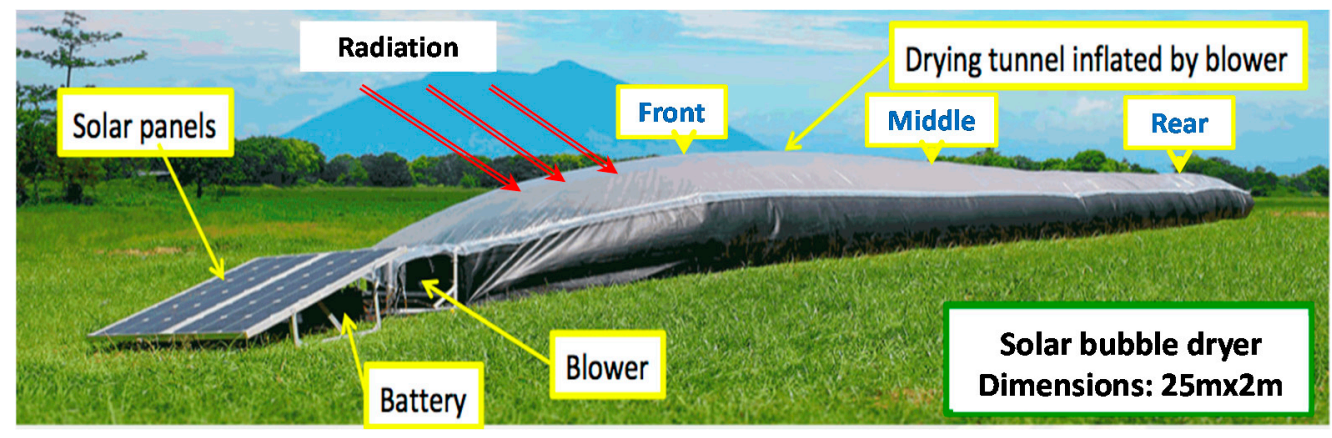

Figure 1. Original Solar Bubble Dryer (SBD) for paddy drying.

\subsection{Experiment and Measurements}

The experiment was conducted in May-June 2019 at the Zeigler Experiment Station (ZES) of the International Rice Research Institute (IRRI) in Laguna, Philippines (14.148 ${ }^{\circ} \mathrm{N}, 121.267^{\circ} \mathrm{E}$ ). The Philippine weather consists of rainy and non-rainy seasons. Climate data at the research site in 2018 are shown in Figure 2. Solar radiation during the day time is in the range of $400-600 \mathrm{~W} \mathrm{~m}^{-2}$. Average ambient temperature and $\mathrm{RH}$ in the day time are $28-32{ }^{\circ} \mathrm{C}$ and $60-70 \%$, respectively.

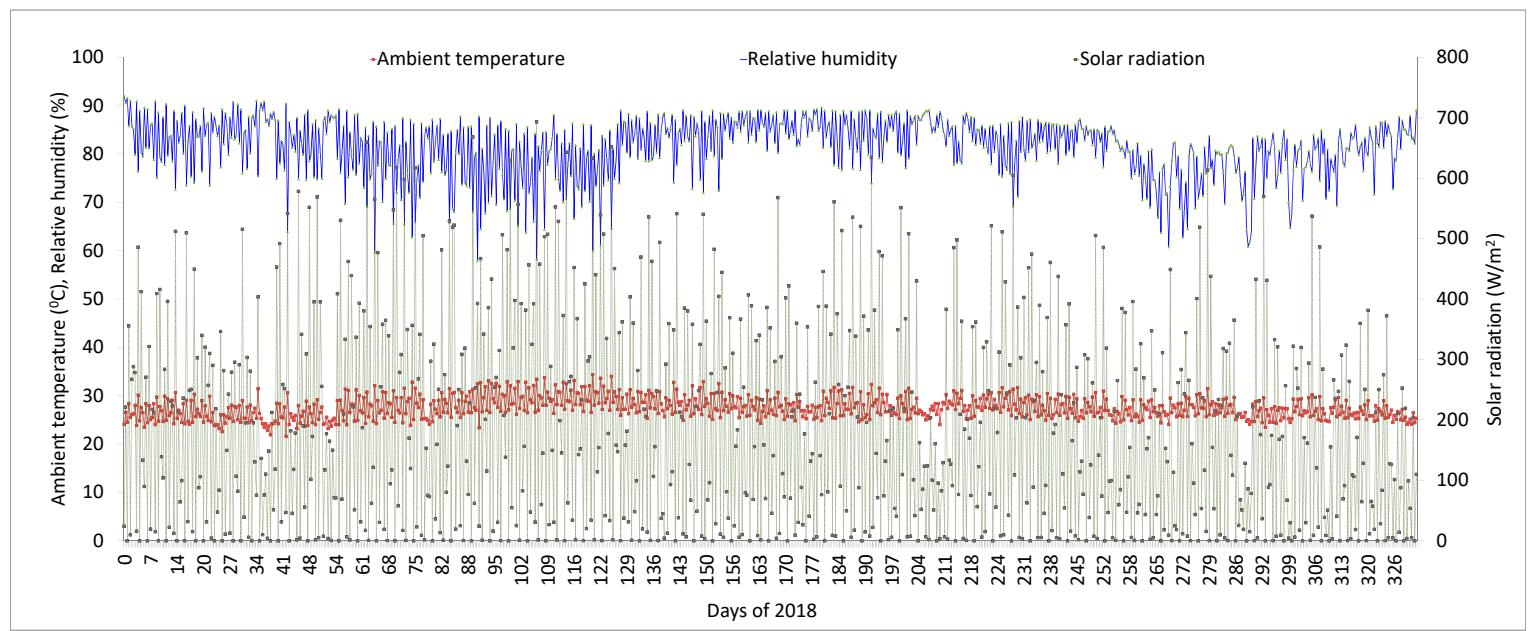

Figure 2. Ambient temperature, RH, and solar radiation in Los Baños, Philippines in 2018 (data were collected by the UPLB National Agromet Station).

The analysis was based on three drying batches with $10 \mathrm{~kg}$ of oyster mushroom each. Table 1 shows the investigated parameters representing the drying characteristics, cost, and benefits. The MC of the product was determined by the drying oven method [31] and then translated into the drying rate or reduction rate of $\% \mathrm{MC}$ per hour during the drying process $\left(\% \mathrm{MC} \mathrm{h}^{-1}\right)$. Samples for $\mathrm{MC}$ measurements were collected at the front, middle, and rear positions in the drying tunnel (Figure 1) every $2 \mathrm{~h}$. Air temperature (AT, i.e., ambient and drying air) and $\mathrm{RH}$ were measured using a datalogger [32]. The AT and RH sensors were located at 3 positions (front, middle, and rear) along the drying tunnel (Figure 1). Carbon (C) and Nitrogen (N) contained in mushroom before and after drying were the only nutrient parameters chosen to represent the product quality. In addition, mushroom color was also observed as a quality indicator. Economic feasibility of this technology was determined through the drying cost, mushroom prices, and financial sensitivity analysis for the Philippine context. 
Table 1. The parameters included in the investigation of mushroom drying.

\begin{tabular}{|c|c|c|}
\hline Parameters & Unit & Method \\
\hline Temperature $(\mathrm{T})$ & ${ }^{\circ} \mathrm{C}$ & $\begin{array}{l}\text { Using data logger (EasyLog); the sensors were placed } \\
\text { in ambient air and at } 3 \text { positions inside the SBD) }\end{array}$ \\
\hline Relative humidity (RH) & $\%$ & $\begin{array}{l}\text { Using data logger (EasyLog); the sensors were placed } \\
\text { in ambient air and at } 3 \text { positions inside the SBD) }\end{array}$ \\
\hline $\begin{array}{l}\text { Moisture content }(\mathrm{MC}) \text { in } \\
\text { wet basis of mushroom }\end{array}$ & $\%$ & $\begin{array}{l}\text { Using oven; the samples were collected at } 3 \text { positions } \\
\text { along the SBD and at every } 2 \mathrm{~h}\end{array}$ \\
\hline $\begin{array}{l}\text { Drying rate (reduction of } \\
\text { MC per hour) }\end{array}$ & $\% h^{-1}$ & Calculation based on the drying curve \\
\hline Energy efficiency & $\mathrm{kWh} \mathrm{kg}^{-1}$ & $\begin{array}{l}\text { Calculation based on energy required for machine } \\
\text { production and operation }\end{array}$ \\
\hline GHG emission & $\mathrm{gCO}_{2} \mathrm{e} \mathrm{kg}^{-1}$ & $\begin{array}{l}\text { For a solar dryer, GHG emissions are just accounted for } \\
\text { using emissions caused by machine production }\end{array}$ \\
\hline $\begin{array}{l}\mathrm{C} \text { and } \mathrm{N} \text { contained in } \\
\text { the mushroom }\end{array}$ & $\%$ (d.m.) & $\begin{array}{l}\text { Conducted by a certified lab analysis. The samples } \\
\text { were collected before and after drying }\end{array}$ \\
\hline Drying cost & $\$ \mathrm{US} \mathrm{kg}^{-1}$ & $\begin{array}{l}\text { Including depreciation, maintenance, interest, } \\
\text { and labor cost (no energy cost for SBD). }\end{array}$ \\
\hline
\end{tabular}

\subsection{Energy Efficiency and GHG Emissions of Mushroom Drying Using SBD}

Energy efficiency $\left(\mathrm{kWh} \mathrm{kg}^{-1}\right)$ and GHG emission $\left(\mathrm{kgCO}_{2} \mathrm{e} \mathrm{kg}^{-1}\right)$ were calculated for drying of $1 \mathrm{~kg}$ of dry mushroom equivalent at $8 \% \mathrm{MC}$. For the SBD, which only uses solar energy, machine production with a depreciation in a life span of 5 years, and labor are taken into account for energy efficiency while machine production is the only factor considered in GHG emission. This analysis was conducted similarly as that reported in [30].

Materials used in the production of the SBD are mainly plastic, photovoltaic cell, charge controller, battery, and the blower. These material inputs and their energy and GHG emission factors are shown in Table 2. The conversion factors were obtained from the database of Ecoinvent 3 [33] incorporated in the SIMAPRO software [34]. In addition, the energy conversion factor of labor for operation was $0.89 \mathrm{MJ} \mathrm{h}^{-1}$ obtained from [35,36].

Table 2. Input materials for the SBD production and conversion factors of energy and greenhouse gas (GHG) emission.

\begin{tabular}{|c|c|c|c|c|c|c|}
\hline \multirow[t]{2}{*}{ Parameters } & \multicolumn{2}{|c|}{$\begin{array}{l}\text { Input Materials for } \\
\text { SBD Production }\end{array}$} & \multicolumn{2}{|c|}{ Energy } & \multicolumn{2}{|c|}{ GHG Emission } \\
\hline & Unit & Total Input & Unit & Value & Unit & Value \\
\hline Plastic firm & $\mathrm{kg}$ & 31 & $\mathrm{MJ} \mathrm{kg}^{-1}$ & 10.3 & $\mathrm{kgCO}_{2} \mathrm{e} \mathrm{kg}^{-1}$ & 0.594 \\
\hline Photovoltaic cell & $\mathrm{m}^{2}$ & 0.55 & $\mathrm{MJ} \mathrm{m}{ }^{-2}$ & 2880 & $\mathrm{kgCO}_{2} \mathrm{e} \mathrm{m}^{-2}$ & 175 \\
\hline Charge controller & unit & 1 & MJ unit ${ }^{-1}$ & 646 & $\mathrm{kgCO}_{2} \mathrm{e}$ unit $^{-1}$ & 44.3 \\
\hline Battery & unit & 1 & MJ unit ${ }^{-1}$ & 5260 & $\mathrm{kgCO}_{2} \mathrm{e}$ unit $^{-1}$ & 411 \\
\hline Blower & unit & 1 & MJ unit ${ }^{-1}$ & 472 & $\mathrm{kgCO}_{2} \mathrm{e}$ unit $^{-1}$ & 27.3 \\
\hline
\end{tabular}

\subsection{Cost-Benefit Analysis}

Mushroom drying costs accounted for depreciation, maintenance, interest, and labor for handling and operation (Table 3). Investment costs for the SBD were based on the existing SBD price in the market while other parameters were obtained from our assessments at the research sites in 2019. We used the drying time results from the experiment (about 3 days for two batches) for calculating the total capacity of the dryer in a year. Effects of climatic factors (i.e., radiation, ambient temperature, and $\mathrm{RH}$ ) on drying time, capacity, and cost-benefits were taken into account through a sensitivity analysis. 
Table 3. Parameters for cost-benefits analysis.

\begin{tabular}{|c|c|c|c|}
\hline Items & Unit & Value & Source \\
\hline Capacity & $\mathrm{kg}$ fresh mushroom batch ${ }^{-1}$ & 30 & Based on the trial (for full capacity) \\
\hline SBD Investment cost & $\$ \mathrm{US} \mathrm{t}^{-1}$ & 1855 & Based on the existing SDB price \\
\hline Life span & year & 5 & Based on the existing SBD use \\
\hline $\begin{array}{l}\text { Time of operation } \\
\text { per year }\end{array}$ & day year ${ }^{-1}$ & 200 & $\begin{array}{l}\text { Assumed (considering the climate } \\
\text { data shown in Figure 2) }\end{array}$ \\
\hline Maintenance & $\%$ (of investment cost) & 10 & Based on the existing SBD use \\
\hline Interest & $\%$ year $^{-1}$ & 8 & Philippine data \\
\hline Labor & $\$ U_{S} h^{-1}$ & 0.65 & Philippine data \\
\hline Fresh mushroom price & $\$ \mathrm{US} \mathrm{kg}^{-1}$ & $0.7-0.8$ & Philippine data \\
\hline Dry mushroom price & $\$ \mathrm{US} \mathrm{kg}^{-1}$ & $10-12$ & Philippine data \\
\hline
\end{tabular}

\subsection{Statistical Analysis and Software}

The analysis of variance (ANOVA), single factor, and F-Test two-sample for variances tools incorporated in Excel were used to evaluate the effects of the drying process on $\mathrm{C}$ and $\mathrm{N}$ contents in fresh and dry mushrooms before and after drying, respectively. Energy efficiency analysis was based on the cumulative energy demand 1.09 method [34]. $\mathrm{CO}_{2}$-equivalent analysis was based on the global warming impact factor for 100 years (GWP-100a) obtained from the IPCC [37].

\section{Results}

\subsection{Adaptation of the SBD for Mushroom Drying}

Figure 3a shows the schematic diagram of the modified SBD for mushroom drying. The existing SBD originally used for paddy grain drying was adapted with an additional perforated floor for elevating the mushrooms (Figure 3b). This perforated floor consists of a net and supporting frame made of inflated plastic beams to be deflatable together with the SBD when they are not in use. This modification enables the drying air moving both on the top and underneath of the mushrooms to increase drying efficiency and prevent them from sticking on the bottom plastic film (if the SBD does not have a perforated floor). The drying tunnel bubble is maintained by the blower during its operation (Figure 3c). During rainy periods or at night when the RH of ambient air is higher than $75 \%$, the SBD blower turns off and the bubble is deflated (Figure 3d) to avoid rewetting the mushroom product.

\subsection{Drying Characteristics}

Figure 4 shows the MC of the mushrooms at three positions (front, middle, rear) along the SBD during the 3 drying batches. The actual drying process happened during the day time, from 10:30 to 16:30 (corresponding to 0-6 drying hours in Figure 4) and from 6:30 to 10:30 of the next day (corresponding to 20-24 drying hours in Figure 4). The MC reduction rate of the mushrooms at the rear positions is higher than that at front and middle positions along the drying tunnel because the increase of solar energy in the drying air with increasing time while flowing through bubble. This is reflected by the increase of temperature and reduction of $\mathrm{RH}$ of drying air from the front to rear positions (Figure 5). Its MC quickly reduced from $90 \%$ down to $40-60 \%$ within $2-4 \mathrm{~h}$ at the early drying stage depending on radiation and the air's temperature and $\mathrm{RH}$, which is important since mushrooms are perishable. The drying rate of this stage is $10-20 \% \mathrm{~h}^{-1}$. There was no MC reduction or significant $\mathrm{MC}$ increase during the night. During the next day, the drying rate was reduced, at $2-5 \% \mathrm{~h}^{-1}$ when the mushroom MC was lower than $30 \%$ for batches 1 and 3; and $10-15 \% \mathrm{~h}^{-1}$ when the mushroom MC was lower than $50 \%$ for batch 2 . 


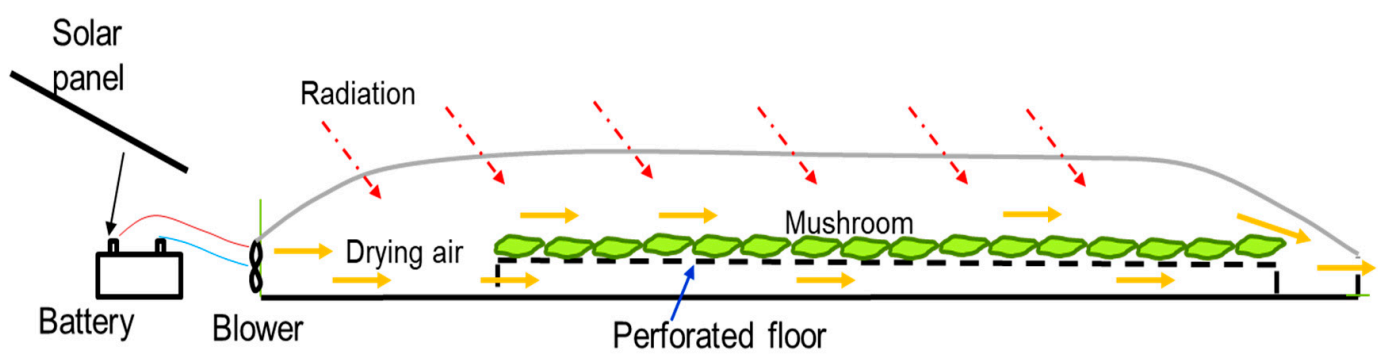

(a)

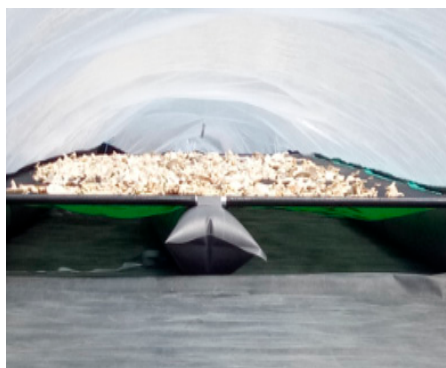

(b)

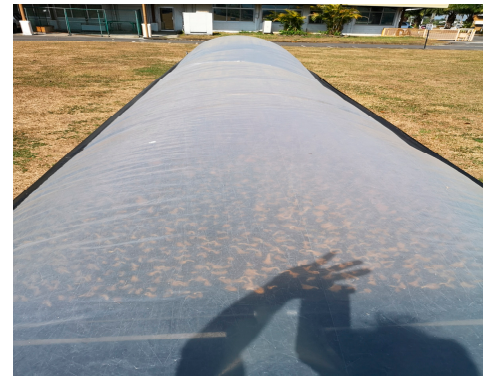

(c)

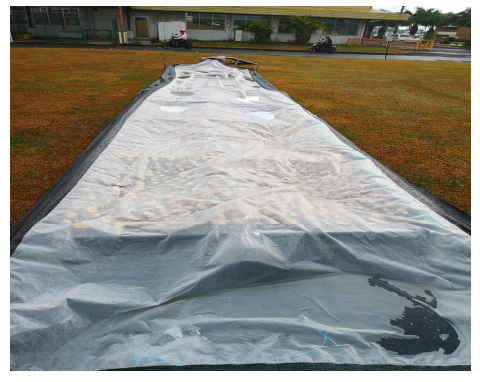

(d)

Figure 3. (a). Schematic diagram of the modified SBD for mushroom drying; (b). Perforated floor (bubble dryer bed) and oyster mushroom inside the SBD; (c). The SBD during drying (day time); (d). The SBD during non-working time (night).

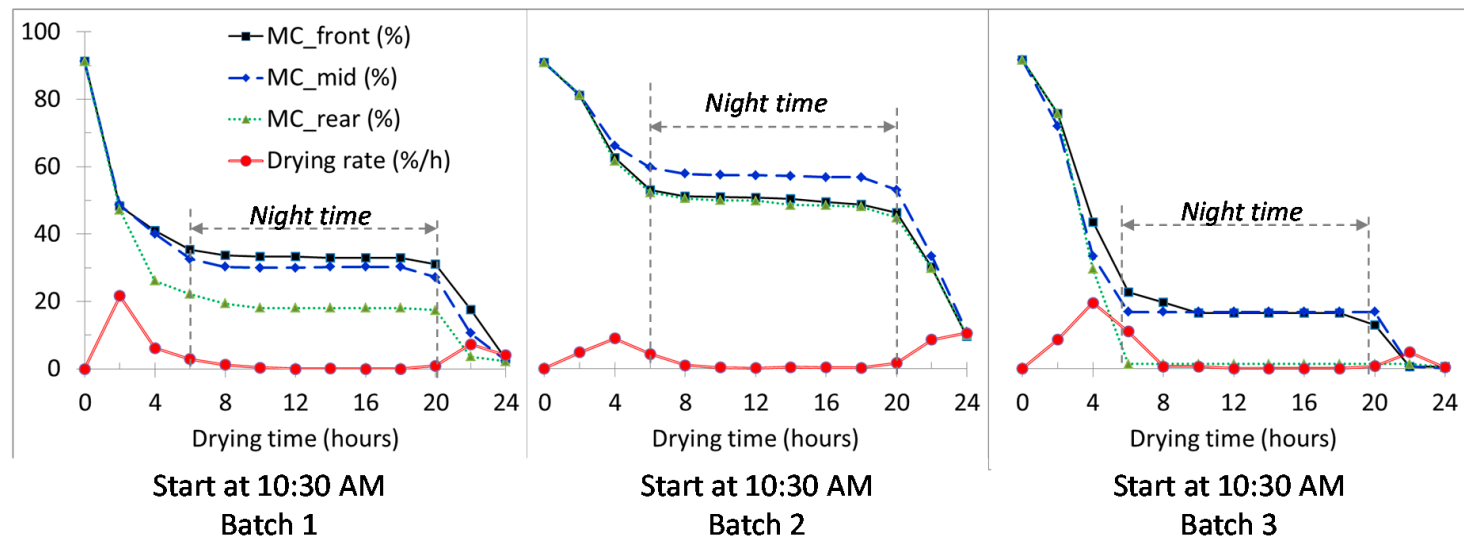

Figure 4. Profile of mushroom MC reduction and drying rate at 3 positions (front, middle, rear) along the SBD during the 3 drying batches.

\subsection{Quality of Mushroom Product}

Table 4 shows the $\mathrm{C}$ and $\mathrm{N}$ contents in dry matter in fresh and dry mushrooms before and after drying, respectively. The drying process did not significantly affect $\mathrm{C}$ but caused a slight reduction of $\mathrm{N}$ contained in the mushrooms. C dry matter content was $44-45 \%$ and not significantly different between fresh and dry mushrooms. N dry matter content in dry mushrooms was $4.8 \%$, lower by $5.8 \%$ than that of fresh mushrooms. On the other hand, the color of dry mushrooms still remained white-cream (Figure 6). The product was characterized as having "good quality" by several consumers and dry mushroom processers. 


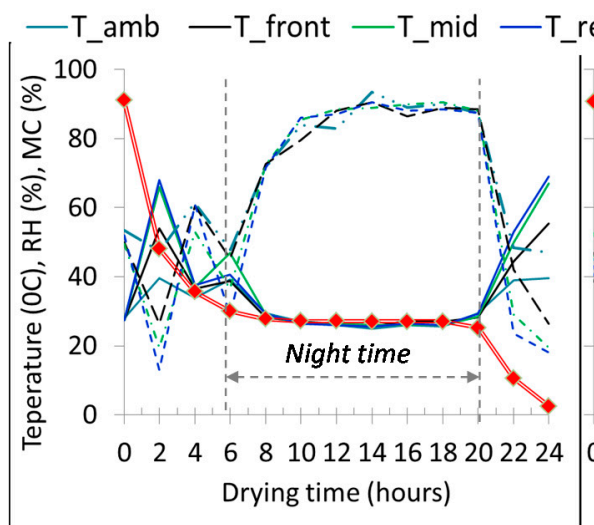

Start at 10:30 AM

Batch 1

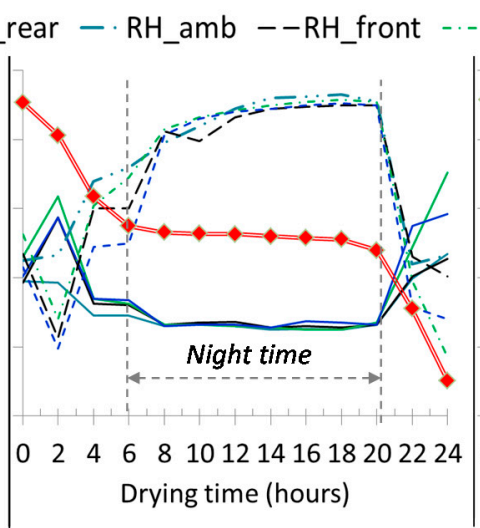

Start at 10:30 AM

Batch 2

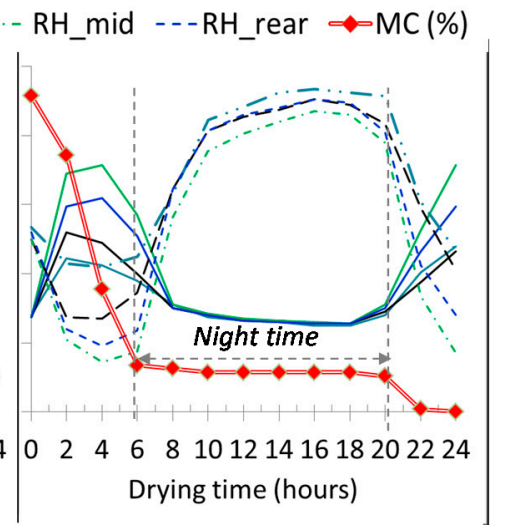

Start at 10:30 AM

Batch 3

Figure 5. Correlation of ambient temperature, $\mathrm{RH}$, and mushroom $\mathrm{MC}$ reduction during 3 drying batches.

Table 4. $\mathrm{C}$ and $\mathrm{N}$ contents of mushrooms before and after drying.

\begin{tabular}{ccccc}
\hline \multirow{2}{*}{ Batch } & \multicolumn{2}{c}{ C (\%) } & \multicolumn{2}{c}{ N (\%) } \\
\cline { 2 - 5 } & Fresh & Dry & Fresh & Dry \\
\hline 1 & 45.2 & 44.5 & 5.19 & 4.82 \\
2 & 44.4 & 44.1 & 5.12 & 4.79 \\
3 & 44.3 & 44.1 & 5.04 & 4.79 \\
Average & 44.6 & 44.2 & $5.1^{\mathrm{a}}$ & $4.8^{\mathrm{b}}$ \\
\hline
\end{tabular}

The average numbers in $\mathrm{C}$ and $\mathrm{N}$ followed by different letters $\left({ }^{\mathrm{a}}\right.$ and $\left.{ }^{\mathrm{b}}\right)$ are significantly different by $F$-test at 0.05 level, while numbers not followed by a letter are not significant.

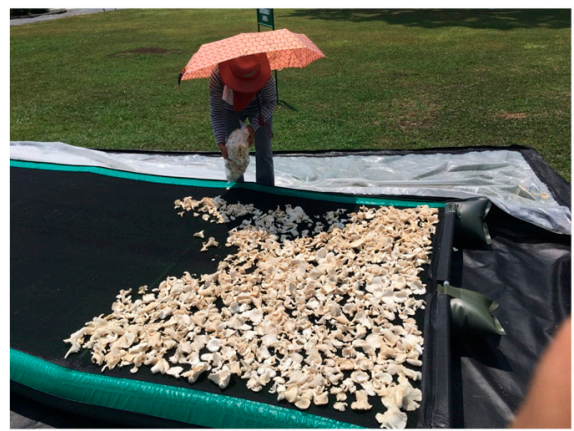

Fresh mushroom (90-95\% MC)

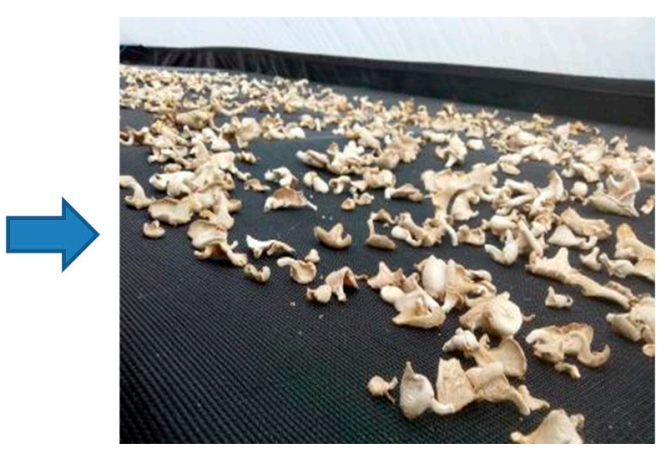

Dry mushroom (5-10\% MC)

Figure 6. Fresh and dry oyster mushrooms before and after drying.

\subsection{Energy Efficiency, GHG Emissions, and Cost-Benefits of Mushroom Drying}

Figure 7 shows energy efficiency, GHG emissions, and cost for drying $1 \mathrm{~kg}$ of oyster mushroom. The drying process for reducing the MC of $90 \%$ of fresh mushroom down to $8 \%$ of dry mushroom required $1.27 \mathrm{kWh}$ (or $4.57 \mathrm{MJ}$ ) per $\mathrm{kg}$ of dried product. This energy consisted of machine production depreciation (80\%) and labor (20\%). This operation emitted $0.33 \mathrm{~kg} \mathrm{CO}_{2} \mathrm{e}$ per $\mathrm{kg}$ of dry product, which was only from machine manufacturing as it used only solar energy. Drying cost was 1.86 \$US per kg of dry product, consisting of depreciation (43\%), labor cost (48\%), and bank interest ( $8 \%$ ). 


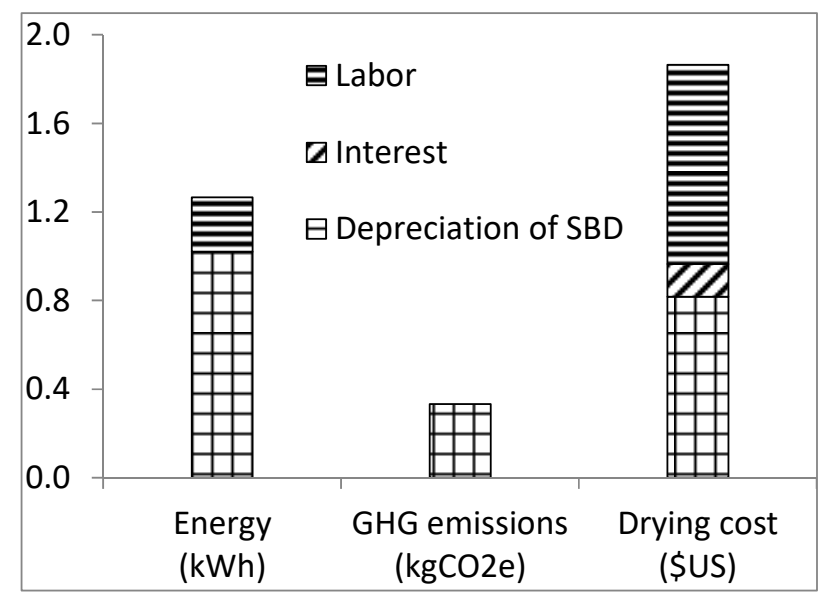

Figure 7. Energy efficiency, GHG emissions, and cost for drying $1 \mathrm{~kg}$ (dry product) of oyster mushroom.

Figure 8 shows the sensitivity analysis of net profit and payback period for a drying service using the SBD for oyster mushroom production. With an annual capacity of $500 \mathrm{~kg}$ dry mushroom, the net profit will reach 468-1468 \$US year ${ }^{-1}$ and the investment cost will breakeven at 1.3-4.0 years corresponding to the selling price of dry mushroom of $10-12 \$ \mathrm{US} \mathrm{kg}^{-1}$ (Figure 8a). On the other hand, with the assumption of the drying capacity changing from 400 to $600 \mathrm{~kg}$ dry mushroom per year as affected by climatic factors, the net profit would range from $678-$ to1258 $\mathrm{kg}_{\text {year }}{ }^{-1}$ (Figure 8b).

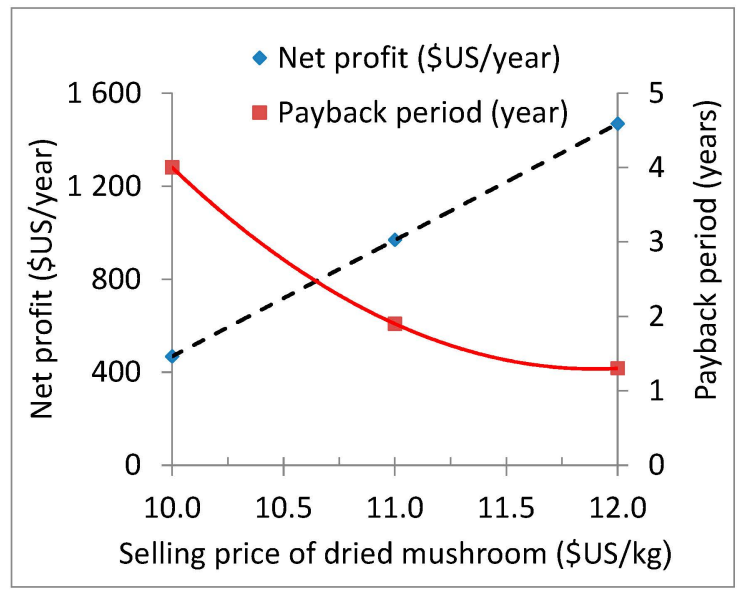

(a)

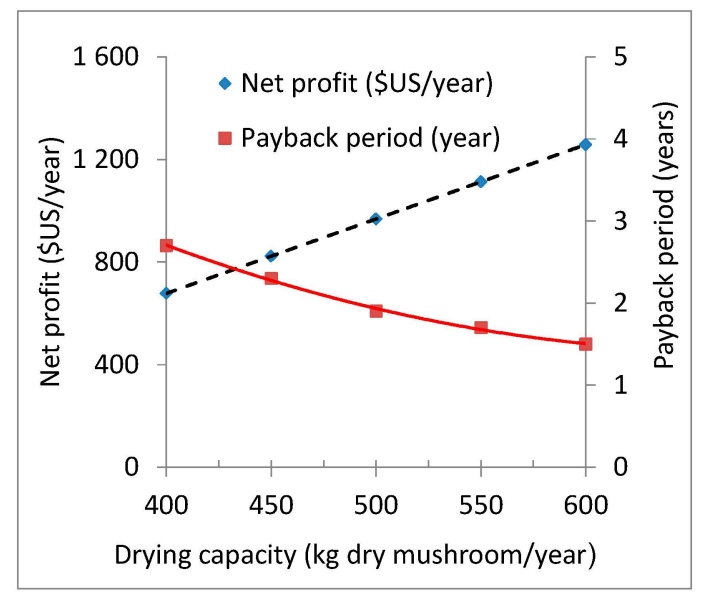

(b)

Figure 8. (a) Effects of dry mushroom selling price on the net profit and payback period of a service using SBD for mushroom drying; (b) effects of drying capacity on the net profit and payback period of a service using SBD for mushroom drying.

\section{Discussion}

This research, while focused more on the structure of the dryer and mushroom drying process, lacked an in-depth assessment on product quality represented by factors such as water activity, product color quantification, yeast and molds, and other spoilage bacteria. On the other hand, it created a new solution to improve the inflatable solar dryer. These limitations are recommended for further research. Furthermore, this study only generated data from an experiment conducted in the Philippines with the specific atmospheric environment and solar radiation of that locality. Other environments with more humidity and less radiation could result in higher drying time, energy requirements, GHG emission, and drying costs due to the increase of labor and reduction of annual drying capacity. 
Cost-benefits are strongly affected by drying capacity, which depends on climate factors, such as ambient temperature, $\mathrm{RH}$, and solar radiation. Within this research, we conducted two analyses based on (1) drying capacity resulting from the experiment (Figure 7) and (2) sensitivity analysis for the change of drying capacity, which causes the changes of depreciation and labor productivity as well as the annual income (Figure 8b). Nevertheless, additional research on modeling of integrating among drying process, product quality, and economics should be conducted to comprehensively address these flaws.

The actual average drying time (excluding night time) for oyster mushroom using this SBD of $8-10 \mathrm{~h} \mathrm{batch}^{-1}$, was shorter than sun drying reported in several studies. Rama and John reported that sun drying for oyster mushroom with the ambient temperature of $21.6-35.7^{\circ} \mathrm{C}$ took $12 \mathrm{~h} \mathrm{batch}{ }^{-1}$ [38]. Maray et al. reviewed that the total drying time (including night time) takes about 3 days [39]. This could be because of the difference in weather, solar radiation, and particularly the improved drying efficiency generated by the SBD functioning as a combined solar collector and dryer. Drying time of this SBD technology was similar to that of cabinet solar and mechanical drying, which takes about 7-10 $\mathrm{h}$, as reported in two studies [40,41].

In this research, we analyzed the $\mathrm{C}$ and $\mathrm{N}$ contents of mushroom while the other important parameters, such as protein and amino acids, should also be considered when discussing mushroom quality $[39,41]$. Nevertheless, these factors are mainly affected by drying temperature and drying time [40], which are advantageous when using the SBD, compared to sun-drying. The convection-airflow passing through the solar bubble regulates the drying temperature and avoids too high of a temperature (e.g., more than $55^{\circ} \mathrm{C}$ ), which usually happens in sun-drying at noon in the dry season. Furthermore, the actual drying time of $8-10 \mathrm{~h}$ within 1.5 days does not cause mushroom decay as indicated by the analysis of $\mathrm{N}$ content and mushroom color observed before and after drying.

Although energy efficiency, GHG emissions, and cost-benefits were not the major focus of this research, these parameters would provide useful aspects for further research and investments, such as the comparative analyses on economic feasibility, energy efficiency, and environmental footprint of different mushroom processing technologies. The financial analysis for a specific case in the Philippines resulted in a net profit that was $20 \%$ higher than the investment cost per year and the payback period was 4 years compared to the life span of 5 years of the SBD. However, the net profit can be significantly increased by increasing the SBD capacity and reducing labor cost. This research, thus, created a promising technology for farmers and would add a significant value to farmers' income as well as diversified nutrient-rich food.

\section{Conclusions}

The adaptation of SBD and drying performance profile resulting from this research illustrated that it is a promising technology for mushroom drying at the farm scale. The SBD with a perforated floor added ensured the quality without any requirement of mixing or turning of the mushroom during drying. Mushroom MC was reduced from $90 \%$ down to $40-60 \%$ within $2-4 \mathrm{~h}$, corresponding to the drying rate at this stage of $10-20 \% \mathrm{~h}^{-1}$. At the next stage of reducing MC down to $8-10 \%$, the drying process took about $4-6 \mathrm{~h}$ corresponding to the drying rate of $2-10 \% \mathrm{~h}^{-1}$. The drying process caused a slight reduction of $\mathrm{N}$ contents from $5.1 \% \mathrm{~N}$ (dry matter) down to $4.8 \%$ (dry matter). However, the color of the dried mushrooms still remained white-cream. The drying process required $1.27 \mathrm{kWh}$ (or $4.57 \mathrm{MJ}$ ), emitted $0.33 \mathrm{~kg} \mathrm{CO}_{2} \mathrm{e}$, and created an input cost of $1.86 \$ \mathrm{US}$ per $\mathrm{kg}$ of dry product. The SBD can reach a capacity of $500 \mathrm{~kg}$ dry mushroom per year. This for a specific case in the Philippines it can generate a net profit of 468-1468 \$US year ${ }^{-1}$ and the investment will break even at 1.3-4.0 years corresponding to the selling price of dry mushroom of $10-12 \$ \mathrm{US} \mathrm{kg}^{-1}$. With the assumption of the drying capacity changing from 400 to $600 \mathrm{~kg}$ dry mushroom per year as affected by climate factors, the net profit would range from 678 to $1258 \mathrm{~kg}_{\mathrm{year}}{ }^{-1}$. 
Author Contributions: Conceptualization, N.V.H.; Data curation, C.B. and A.P.R.; Methodology, N.V.H., C.B., L.A.F. and M.G.; Software, N.V.H.; Supervision, M.G.; Validation, M.T.; Writing-original draft, N.V.H.; Writing-review \& editing, N.V.H., L.A.F., C.B., and M.G. All authors have read and agreed to the published version of the manuscript.

Funding: This research was conducted under the project "Sustainable Rice Straw Management for Bioenergy, Food, and Feed in the Philippines", Grant No. 101101-03-042-2018, funded by the Philippine Department of Agriculture. Time of Nguyen Van Hung and Martin Gummert (lead authors of the research) was partially funded by the Swiss Agency for Development and Cooperation (SDC) through the CORIGAP project [Grant No. 81016734] and the Flagship Program 2, Upgrading Rice Value Chains of the CGIAR Research Program on Rice (RICE).

Acknowledgments: The authors acknowledge the valuable support of the management and research support teams in the International Rice Research Institute and the support of Eduardo Secretario for his field-activity assistance.

Conflicts of Interest: The authors declare no conflict of interest.

\section{References}

1. Grujic, B.D.; Potocnik, I.; Duduk, B.; Vujcic, Z. Spent mushroom compost as substrate for the production of industrially important hydrolytic enzymes by fungi Trichoderma spp. and Aspergillus niger in solid state fermentation. Int. Biodeterior. Biodegrad. 2015, 104, 290-298. [CrossRef]

2. Corales, R.G.; Sajor, J.T.; Truc, N.T.T.; Hien, P.H.; Ramos, R.E.; Bautista, E.; Tado, C.J.M.; Ompad, V.; Son, D.T.; Van Hung, N. Rice-Straw Mushroom Production. In Sustainable Rice Straw Management; Gummert, M., Van-Hung, N., Chivenge, P., Douthwaite, B., Eds.; Springer: Cham, Switzerland, 2020.

3. Yang, W.; Guo, F.; Wan, Z. Yield and size of oyster mushroom grown on rice/wheat straw basal substrate supplemented with cotton seed hull. Saudi J. Biol. Sci. 2013, 20, 333-338. [CrossRef] [PubMed]

4. Chang, S.T. The world mushroom industry: Trends and technological development. Int. J. Med. Mush. 2006, 8, 297-314. [CrossRef]

5. Obodai, M.C.O.; Vowotor, K.A. Comparative study on the growth and yield of Pleurotus ostreatus mushroom on different lignocellulosic by-products. J. Ind. Microb. Biotechnol. 2003, 30, 146-149. [CrossRef]

6. Zhang, R.; Li, X.; Fadel, J.G. Oyster mushroom cultivation with rice and wheat straw. Bioresour. Technol. 2002, 82, 277-284. [CrossRef]

7. Bhattacharya, M.; Srivastav, P.R.; Mishra, H.N. Thin-layer modeling of convective and microwave-convective drying of oyster mushroom (Pleurotus ostreatus). J. Food Sci. Technol. 2015, 52, 2013-2022. [CrossRef]

8. Khatuna, S.; Islamb, A.; Cakilciogluc, U.; Gulerd, P.; Chatterjee, N.C. Nutritional qualities and antioxidant activity of three edible oyster mushrooms (Pleurotus spp.). NJAS-Wagening. J. Life Sci. 2015, 72-73, 1-5. [CrossRef]

9. Garcha, H.S.; Khanna, P.K.; Soni, G.L. Nutritional importance of mushrooms. In Mushroom Biology and Mushroom Products, Proceedings of the First International Conference; Chang, S.T., Chiu, B.S., Eds.; The Chinese University of Hong Kong: Hong Kong, China, 1993; pp. 227-236.

10. Demont, M.; Ngo, T.T.T.; Van Hung, N.; Duong, G.P.; Dương, T.M.; Hoang, N.T.; Custodio, M.C.; Quilloy, R.; Gummert, M. Rice straw value chain and a case study for rice straw mushroom value chain in Vietnam. In Sustainable Rice Straw Management; Gummert, M., Van-Hung, N., Chivenge, P., Douthwaite, B., Eds.; Springer: Cham, Switzerland, 2020.

11. Van Nguyen, H.; Nguyen, C.D.; Van Tran, T.; Hau, H.D.; Nguyen, N.T.; Gummert, M. Energy Efficiency, Greenhouse Gas Emissions, and Cost of Rice Straw Collection in the Mekong River Delta of Vietnam. Field Crops Res. 2016, 198, 16-22. [CrossRef]

12. Van-Hung, N.; Detras, M.C.M.; Migo, M.V.; Quilloy, R.; Balingbing, C.; Chivenge, P.; Gummert, M. Rice Straw Overview: Availability, Properties, and Management Practices. In Sustainable Rice Straw Management; Gummert, M., Van-Hung, N., Chivenge, P., Douthwaite, B., Eds.; Springer: Cham, Switzerland, 2020.

13. Kulshreshtha, M.; Singh, A.; Vipul, D. Effect of drying conditions on mushroom quality. J. Eng. Sci. Technol. 2009, 4, 90-98.

14. Sandhu, K.S.; Aggarwal, P. Steeping preservation of mushrooms (Agaricus bisporus). J. Res. Punjab Agric. Univ. 2001, 38, 53-57.

15. Yılmaz, F.M.; Bastığlu, A.Z. Production of phenolic enriched mushroom powder as affected by impregnation method and air-drying temperature. LWT-Food Sci. Technol. 2020, 122. [CrossRef]

16. Kurt, A.; Genccelep, H. Enrichment of meat emulsion with mushroom (Agaricus bisporus) powder: Impact on rheological and structural characteristics. J. Food Eng. 2018, 237, 128-136. [CrossRef] 
17. Okafor, J.N.C.; Okafor, G.I.; Ozumba, A.U.; Elemo, G.N. Quality characteristics of bread made from wheat and Nigerian oyster mushroom (Pleurotus plumonarius) powder. Pak. J. Nutr. 2012, 11, 5-10. [CrossRef]

18. Bano, Z.; Rajarathnam, S.; Shashirekha, M.N. Mushrooms-Unconventional single cell protein for a conventional consumption. Indian Food Pack. 1992, 46, 20-31.

19. Das, I.; Arora, A. Alternate microwave and convective hot air application for rapid mushroom drying. J. Food Eng. 2018, 223, 208-219. [CrossRef]

20. Amuthan, G.; Visvanathan, R.; Kailappan, R.; Sreenarayanan, V.V. Studies on osmo-air drying of milky mushroom, Calocybe Indica. Mush. Res. 1999, 8, 49-52.

21. Kar, A.; Gupta, D.K. Osmotic dehydration characteristics of button mushrooms. J. Food Sci. Technol. 2001, 38, 352-357.

22. Sevik, S.; Aktas, M.; Dogan, H.; Kocak, S. Mushroom drying with solar assisted heat pump system. Energy Convers. Manag. 2013, 72, 171-178. [CrossRef]

23. Singh, S.K.; Narain, M.; Kumbhar, B.K. Effect of drying air temperatures and standard pretreatments on the quality of fluidized bed dried button mushroom (Agaricus bisporus). Indian Food Pack. 2001, 55, 82-86.

24. Rai, R.D.; Arumuganathan, T. Postharvest Technology of Mushrooms. 2008. Available online: https: //nrcmushroom.org/Bull_PHT.pdf (accessed on 11 June 2020).

25. Amer, B.M.A.; Hossain, M.A.; Gottschalk, K. Design and performance evaluation of a new hybrid solar dryer for banana. Energy Conver. Manag. 2010, 51, 813-820. [CrossRef]

26. Boughali, S.; Benmoussa, H.; Bouchekima, B.; Mennouche, D.; Bouguettaia, H.; Bechki, D. Crop drying by indirect active hybrid-solar-electrical dryer in the eastern Algerian Septentrional Sahara. Sol. Energy 2009, 83, 2223-2232. [CrossRef]

27. Reyes, A.; Mahn, A.; Cubillos, F.; Huenulaf, P. Mushroom dehydration in a hybrid-solar dryer. Energy Convers. Manag. 2013, 70, 31-39. [CrossRef]

28. GrainPro, Bubble Dryer. Available online: https://grainpro.com/grainpro-bubble-dryer (accessed on 11 June 2020).

29. Salvatierra-Rojas, A.; Nagle, M.; Gummert, M.; Bruin, T.; Müller, J. Development of an inflatable solar dryer for improved postharvest handling of paddy rice in humid climates. Int. J. Agric. Biol. Eng. 2017, 10, 269-282. [CrossRef]

30. Nguyen-Van-Hung; Tran-Van-Tuan; Meas, P.; Tado, C.J.M.; Kyaw, M.A.; Gummert, M. Best practices for paddy drying: Case studies in Vietnam, Cambodia, Philippines, and Myanmar. Plant Prod. Sci. J. 2019, 22, 107-118. [CrossRef]

31. ASAE. Moisture measurement of grain and seeds. In ASAE Standard, 29th ed.; ASABE: St. Joseph, MI, USA, 1982; p. 3521. Available online: https://engineering.purdue.edu/ \{\}abe305/moisture/html/page12.htm (accessed on 11 June 2020).

32. Lascar. Easylog Datalogger. Available online: https://www.lascarelectronics.com/easylog-el-usb-2 (accessed on 11 June 2020).

33. ECOINVENT. Implementation of Ecoinvent 3. Available online: http://www.ecoinvent.org/partners/resellers/ implementation-of-ecoinvent-3/implementation-of-ecoinvent-3.html (accessed on 11 June 2020).

34. SIMAPRO. SIMAPRO-LCA Software. Available online: https://www.pre-sustainability.com/simapro (accessed on 11 June 2020).

35. Ainsworth, B.E.; Haskell, W.L.; Herrmann, S.D.; Meckes, N.; Bassett, J.D.R.; Tudor-Locke, C.; Greer, J.L.; Vezina, J.; Whitt-Glover, M.C.; Leon, A.S. Compendium of physical activities: A second update of codes and MET values. Med. Sci. Sport. Exerc. 2011, 43, 1575-1581. [CrossRef]

36. Quilty, R.J.; McKinley, J.; Pede, V.O.; Buresh, R.J.; Correa, J.T.Q.; Sandro, J. Energy efficiency of rice production in farmers' fields and intensively cropped research fields in the Philippines. Field Crop. Res. 2014, 168, 8-18. [CrossRef]

37. IPCC. Emissions Factor Database. 2013. Available online: http://www.ghgprotocol.org/Third-PartyDatabases/IPCC-Emissions-Factor-Database (accessed on 11 June 2020).

38. Rama, V.; John, P. Effect of methods of drying and pretreatments on quality of dehydrated mushroom. Indian Food Pack. 2000, 54, 25-35.

39. Maray, A.; Mostafa, M.; El-Din, A. Effect of pretreatments and drying methods on physico-chemical, sensory characteristics and nutritional value of oyster mushroom. J. Food Process Preserv. 2018. [CrossRef] 
40. Bala, B.K.; Morshed, M.A.; Rahman, M.F. Solar Drying of Mushroom Using Solar Tunnel Dryer. 2009. Available online: https://pdfs.semanticscholar.org/073e/fb15fe273f05cd1b70f97f75839856a158a3.pdf?_ga=2. 68302035.3719813.1589409163-4187258.1589409163 (accessed on 11 June 2020).

41. Ibrahim, T.A.; Adaramola-Ajibola, K.M.; Adesuyi, A.T.; Olanrewaju, S.O.; Akinro, E.B. Effect of pre-treatments and drying methods on the chemical quality and microbial density of wild edible oyster mushroom. Arch. Food Nutr. Sci. 2017, 1, 39-44. [CrossRef]

C 2020 by the authors. Licensee MDPI, Basel, Switzerland. This article is an open access article distributed under the terms and conditions of the Creative Commons Attribution (CC BY) license (http://creativecommons.org/licenses/by/4.0/). 